\title{
Music and Dance Expressions Circles with Mental Health Users: an Experience Report
}

Francisca Bezerra de Oliveira1, Francisco Fábio Marques da Silva1, Maria Lúcia de Oliveira Bezerra1, Maria do Carmo Andrade Duarte de Farias², Ane lara Nonato de Sousa ${ }^{3}$, Amanda Fernandes Machado ${ }^{3}$, Danilo Temóteo da Silva ${ }^{3}$, José Gleyson Pereira Moura ${ }^{3}$, Francisco Demóstenes Abrantes Viana ${ }^{3}$, Gabriel Alexandre da Silva ${ }^{3}$, Thaís Kamilla Alves Pereira ${ }^{3}$, Mário Hélio Antunes Pamplona ${ }^{3}$, Maria Ayrlles Macêdo ${ }^{4}$

\section{Abstract}

Introduction: Mental health care advances through the perspective of the principles of Psychiatric Reform, deconstructing knowledge and ways of dealing with the user in psychological distress, emphasizing the subject, family, community, interdisciplinary work and social inclusion.

Objective: Describing the lived experience and the activities developed in the Extension Project "Music and dance expressions circles with mental health users", the Center for Psychosocial Care (CPC II).

Method: The activities were developed with 15 users of CPC Cajazeiras - Paraíba, Brazil, from October 2014 to March 2015. There was prepared the Final Report of the Extension Project, which served as a basis for this report. For data analysis was sought support in authors who defend the Psychiatric Reform, as well as those working with the theme of music and art.

Results: Regarding the use of music and dance found that are valuable strategies in mental health care, being able to work self-esteem, sociability, communication, joy, commitment and new forms of subjectivity of the users.

Conclusion: In mental health we must dare and develop practices that seek to return to the subject the possibility of genuine creation of its existence, that is, that assist in building relationships expression of creation in which the user re-apropriate of subjectivity, producing singling process one.
1 Academic Unit of Nursing, Teacher Training Center, Federal University of Campina Grande. Cajazeiras, Paraíba, Brazil.

2 Academic Unit of Life Sciences, Teacher Training Center, Federal University of Campina Grande. Cajazeiras, Paraíba, Brazil.

3 Student of Nursing, Academic Unit of Nursing, Federal University of Campina Grande. Cajazeiras, Paraíba, Brazil.

4 Graduate Student in the form of MultiFamily Residence in Health linked to the Health Ministry.

\section{Contact information:}

Francisca Bezerra de Oliveira. Academic Unit of Nursing, Teacher Training Center, Federal University of Campina Grande. Cajazeiras, Paraíba, Brazil.

Address: Rua Irmã Fernanda, no 91, apt $^{\circ}$ 103, Bairro São José. Cajazeiras - PB. CEP: 58.900-000.

झ”oliveirafb@uol.com.br

Keywords

Mental Health; Community Psychiatry; Social Participation; Music Therapy; Social Inclusion. 


\section{Introduction}

Madness was decoded into mental illness in the late eighteenth and early nineteenth century, implying the possibility of lack of Reason, "crazy". So mental patients were unable of the complete reason and therefore free choice; thus, arised the asylum paradigm, so as to isolate the "crazy" in a psychiatric institution because of mental alienation. The care was trampled on moral treatment and aimed at the patient's discipline, the restoration of Reason, ie their freedom. However, asylum, the liberation of the alienated environment, proved to be a place of exclusion, failure and grief of subjectivities [1-2].

The asylum paradigm lasted for approximately half a century worldwide. In Brazil, this paradigm began to be questioned due to: health commodification, chronicity, stigmatization of the mentally ill and working condition, emerging in the late 1970s, the workers in Mental Health Movement, the protagonist in the construction of the Psychiatric Reform [2-3]

The Psychiatric Reform is a complex social process, articulated a set of initiatives operated in the legislative, legal, administrative and cultural, aimed at changing the relationship between society and madness, turning "subject objectified in subjects of law" [3].

In Brazil, from the Psychiatric Reform, new care services in mental health, guided by the Brazilian guidelines of the Unified Health System (SUS), were implanted: Center for Psychosocial Care (CPC), Therapeutic Residences (TR), beds, and comprehensive attention, Mental Health, among others.

These services, nominated to substitute suggest actions whose purpose is to reintegrate the person in mental distress and his family to the social, through an interdisciplinary team, and to establish a different view of attention anchored in the singular therapeutic project (STP) embodied in a set of agreed actions between different stakeholders: users, family members, CPC professional and other services, marking the mental suffering and the need of the user, as central points [4].

In this sense, the CPC in Brazil is a strategic service of daily attention to the mental health patient, in order to meet the madhouse admissions by open reception in the community. Should it be a meeting space, assemblages of subjective experiences, building autonomy, citizenship and social inclusion from the perspective of clinical expanded [4].

The expanded clinic should be a shared path by experts from various fields to meet the complexity of mental suffering, order causality: biological, social, cultural and psychological [5].

Currently, one of the biggest problems facing the CPC symbolizes precisely this need for inter-sectoral work, and basic care, family and communities as partners in the process, through actions, pipelines, and projects, diverse workshops, able to provide (re) integration and the production of new subjectivities to the subject in mental distress [6].

Thus, it is important the dialogue between mental health and art. Art has his way of being that goes through aesthetic and the agency of new subjectivities [7]. The music and dancing are forms of art and experiences that can foster the meeting, the exchange, the existence, listening to the opening, the reception, the joy, the movement, the feeling of belonging, of people who are vulnerable, with feelings of loss: love, work, studies, self-esteem, and interpersonalrelationships [8].

The idea that music and dance can contribute to improving the quality of life of mental health users, boosted the teachers and students of the Academic Unit of Nursing, the Teacher Training Center, the Federal University Campina Grande, sensitive to the issues linked to users of CAPS, to develop the Project of University Extension: "Music and dance expressions circles with mental health users." 
There have as basic assumptions that these individuals in mental distress, despite the limitations and weaknesses, are entitled to a joyful life and citizenship. Also, if postulated that this project through music and dance spaces favor the promotion of selfesteem, improved interpersonal relationships and of users' communications.

There have as basic assumptions that these individuals in mental distress, despite the limitations and weaknesses, are entitled to a joyful life and citizenship. Also, if postulated that this project through music and dance spaces favor the promotion of selfesteem, improved interpersonal relationships and of users' communications.

\section{Method}

The methodological course took place through weekly meetings on Thursdays in the morning, in a room of UFCG, with the participation of teachers and students, linked to the graduate course of Nursing UAENF/CFP/UFCG in the municipality of Cajazeiras, Paraíba, Brazil, for planning activities. The project period was from October 2014 to March 2015. From the signing of the Instrument of Consent by the coordinator of the institution, the music and dance meetings were initiated with 15 intensive and semi-intensive users of CPC II, from pre-established contacts expressed interest in participating in the said project.

The CPC was chosen as space for the development of this extension project by constituting a place of care, rehabilitation, care, interpersonal relationships, and production of new subjectivities for people with mental health problems. This service looks the same time as an activator of health equipment of community resources, user integration, family and society [2-4].

At first, it was decided to conduct a relevant literature to mental health theme and music and dance, aiming to support the efforts related to the project. It is understood that professionals should be aware of and training for the use of a therapeutic resource, so it does not become iatrogenic like any other therapeutic tool indicated inappropriately. Theoretical frameworks are essential to support extension researchers, students in their academic work, enabling travel between empirical data and theory as well as the organization and systematization of the findings [9].

During the months of project development were held 11 meetings, eight in CPC II, lasting about two hours; one in the Circle Worker and two in the CFP/ UFCG in the city of Cajazeiras - PB, with the effective participation of extension staff and participants users of music and dance circle group.

Amid the development of the project, the procedure of the extension staff was permanently and systematically, through regular meetings with discussions and readings relevant to the theme, and uninterrupted meetings for the realization of musical practice with users, making if necessary constant updates of musical repertoire for an adaptation to the singularities and desires of the group, to evaluate the progress of the practical process of activities.

From this perspective, this music and dance project sought to build new forms of subjectivity, of living together with difference, so that society can give continence and demystify the "look" it sees in the person with mental suffering, the threat $[2,4]$.

\section{Results}

Every new experience is generating anxieties, fears. In fact, the first meetings were characterized by a group atmosphere of "seizure" and "expectation"; participants were concerned about the acceptance of the other and what might happen there. Some users have participated in early by putting on the observers' position.

Thus, the first meetings in CPC were characterized by a certain shyness of most users, while others had more extroverted. This is how the interaction 
Frame 1. Stimuli developed during and after the music and dance circles in CPC II.

\begin{tabular}{l|l}
\multicolumn{1}{c|}{ Stimuli } & \multicolumn{1}{c}{ Answers } \\
\hline Cognitive & $\begin{array}{l}\text { The songs sung in the meetings made CPC users remember something experienced throughout their } \\
\text { history, most of the time, good memories that stimulate the memory and the joy of living, providing } \\
\text { physical and mental well being. }\end{array}$ \\
\hline Interpersonal & $\begin{array}{l}\text { We observe that the music and dance made users more personal interaction between the users } \\
\text { themselves and, especially, between these and the academics of nursing; as well as between } \\
\text { professionals and teachers, present in the meetings. We noticed the looks vibrant and excited waiting } \\
\text { for a new date, a new move and a new song. With that, we were slowly gaining the trust of users, } \\
\text { causing them to report their hidden feelings. }\end{array}$ \\
\hline Felf-esteem & $\begin{array}{l}\text { For the simple fact that we are in CPC, maintaining physical and psychological contact through dance, } \\
\text { music and dialogue, we realize that all users feel special and welcomed, making sure that there were } \\
\text { people who cared about and reminded them, thus raising the self-esteem. }\end{array}$
\end{tabular}

Spirituality Some users liked listening to religious songs because they felt closer to God, prayer and bringing tranquility and inner peace.

between them and the project team was being built. After conducting some meetings we noticed a progressive movement of the group, becoming noticeable delivery of rhythm, voice, dance, meetings and agency of subjective experiences, where suffering gave way to joy and the presentation of their own existence.

Besides these activities held weekly in CPC, other meetings were developed in the community, as was the case of group participation on the anniversary of the civic parade in the city of Cajazeiras - PB. On that occasion it was possible to show the beautiful work done by the entire team of CPC professionals and present the project "Music and dance circles with mental health users" to society and the authorities who attended the event. That day was important because it was clear the satisfaction of all present, through dances, hymns and speeches, evidenced mainly from the smile and the joy of users, who instead of isolation, were roaming the landscapes of city, showing that it is possible to live in society.

Another special moment was recorded with the participation of the group in a fellowship, to celebrate the end of year festivities, CPC, being held at the Workers' Circle Cajazeiras, attended by all members and their families. It was a special day in their lives, which along with the staff made the party in a lively environment for a varied repertoire, with special songs year-end.

There are highlighted in Frame 1 responses arising from stimuli developed from the making of the music and dancing circles.

\section{Discussions}

The meetings brought positive results and allowed the construction of expressions singled through emotions expressed by people who interact and identify their actions through musicality, confirming previous studies [10-12].

The music used therapeutically in this work purposed to make the minds of the participants tread unimaginable paths, and enable stimulation of empathic-affective-communicative memory and can be reversed on a strategy for the resumption of feelings and memories of the past, of pleasurable sensations. Music is able to form the soundtrack of our times, enabling a flashback of life, a revival of memories and emotions related to significant 
events, which, in turn, can facilitate the meeting of meanings, stimulus and purpose of existence [13].

Thus, these responses to stimuli evoked by the music and dance revealed a care tool, facilitator of building interpersonal relationships and improved communications. "Thinking in the production of care means listening to the melody and the rhythm of the song sung (or latent) of each, who take care of the delicate and complex task" [4:159].

The music also had the power of calming effect, caused the subjects participating in this project, giving rise to deeper feelings, becoming visible the expressed thoughts of spirituality and faith to the memories of their beliefs, reflecting the increase in health recovery hopes [14].

Self-esteem is also considered a way that the individual pallet against himself or another, and therefore interfere positively or negatively in the way a person deals with the environment and environmental difficulties that this can provide. Thus, it has a close relationship with mental health and the state of psychological and social well-being provided by music [15].

This work enabled us to identify new care technologies in mental health, through musicality, woven every meeting, guided by "an ethic of autonomy, singling and social inclusion" [4]. You must dare, risk and take a step ahead, creating spaces to host meetings, learning, building links, continence and listening in mental health practice.

The group moments here reported moments were lived with intensity, by all participants, both at the time of realization of meetings, as at the time were described. After all, we are talking about life, people, feelings, existential suffering, seeking to build spaces and give voice those who often were prevented from expressing their uniqueness and historicity.

It confirms that mental health from the perspective of the Psychiatric Reform, one must have the understanding "of the practice as a permanent invention, such as production of new approaches
[...], approaches in mental health must be built, not based on scientific truths, but because of ethicalaesthetic-existential efficiencies" [16:161].

The performance of music and dance meetings enabled the improvement, the recovery and the promotion of important aspects of the user, such as self-esteem, communication and interpersonal relations, assisting in the rehabilitation and social inclusion of users in mental distress process. This process was characterized as dynamic, in construction and unfinished.

From the beginning and throughout the development of the activities, it was evidenced the true sense of musical encounters, the proposed objectives, the operating dynamics and its importance in healthier and less painful process contribution of a lifetime. The bond built between the staff and users, from group meetings, enabled a steady improvement in interpersonal relationships, and communicating users.

It was found, every musical encounter, users felt more at ease, but also participating more actively, cheerful way, made suggestions melodies, tones, chords being played, invited project members to dance and sing the microphone. These moments of meeting full enriched the environment, providing satisfaction to the team, knowing that walking was not in vain, and that the strategies disseminated earlier would yield positive results.

This work contributed significantly to the academic training of the participating team, as well as provided an effective and pleasant work with the users of CPC, favoring the creation of bonds. The work set up an opportunity for knowledge exchange that enriched all.

In this sense, the expectations were met, since all the planning was completed plausibly, that is, everything that has been thought out and discussed by the team was successful, contributing to the development and well-being of users, and in general, promoting the restoration of what is right and that they should never be challenged: respect, dignity 
and the desire to be happy. The return came in the midst of the results, thus providing irrefutable improvements in self-esteem, communication and uniqueness of each user, making its lighter burdens and their lives happier.

The biggest difficulties encountered in the course of the activities were related to the lack of appropriate physical structure for holding meetings with the group, despite the given environment for the practices have been the main hall of the CPC would need a more open space, so did not affect the acoustics and made it difficult or body movements of the participants, provided the dance. Another difficulty was to set up a suitable repertoire for performances, due to the need for greater attention and a thorough look at the classification of the songs and their positive effects by adding them to the list for the next meetings and discarding those that provided uncomfortable or negative feelings to thereof.

\section{Conclusion}

From this work it is evident that music can be a valuable strategy of mental health care. With the musicianship it was possible to work self-esteem, sociability, communication, happiness, commitment and new forms of subjectivity. The music is a tool of social integration and has become more and more a means to develop insights and individual sensitivities, walking towards each other, enhancing significantly the human relations.

In mental health There are important practices such as music, that seek to return to the subject in mental distress the possibility of genuine creation of its existence, that is, that assist in building relationships, expression of creation in which the subject reapropriatehimself of subjectivity, producing a singling-out process.

\section{Acknowledgements}

We thank all users and professionals of CPC II of the city of Cajazeiras - PB.

\section{References}

1. Caste IR. A ordem psiquiátrica: a idade do ouro do alienismo. 2 ed. Rio de Janeiro: Graal; 1978.

2. Oliveira FB. Construindo saberes e práticas em saúde mental. João Pessoa: Editora Universitária/UFPB; 2002.

3. Amarante P. Saúde mental e atenção psicossocial. Rio de Janeiro: FIOCRUZ; 2007.

4. Yasui S. Rupturas e Encontros: desafios da reforma psiquiátrica brasileira. Rio de Janeiro: FIOCRUZ; 2010.

5. Cunha GT. A construção da clínica ampliada na atenção básica. São Paulo: Hucitec; 2005.

6. Oliveira FB, Silva AO, Martins AKL, Oliveira NS. Reforma Psiquiátrica: saúde mental no contexto da saúde da família. In: Oliveira FB, Lima Jr JF, Moreira MRC. Resgatando saberes e ressignificando práticas: interfaces no campo da saúde coletiva, Campina Grande: Editora da UFCG; 2012. p. 75-89.

7. Amarante $P$, Nocam F. (Orgs). Saúde mental e arte: práticas, saberes e debates. São Paulo: Zagodoni; 2012.

8. Leonardi J, Pedrão LJ. Canta e danças circulares em saúde mental: uma abordagem baseada no caminho de ser e conviver. In: Amarante P, Nocam F. (Orgs.). Saúde mental e arte: práticas, saberes e debates. São Paulo: Zagodoni, 2012. p. 161-176.

9. Figueiredo NMA. Métodos e metodologia na pesquisa científica. 3 ed. São Caetano do Sul, SP: Yendis; 2008.

10. Mostazo RR, Eloy CB, Pinto LBCS, Castilho ECD. Experiências musicais vivenciadas por usuários de um Centro de Atenção Psicossocial. Revista de Psicologia da UNESP, 2012; 11(2): 131-7. http://www2.assis.unesp.br/revpsico/index.php/revista/article/ viewFile/206/306

11. Silva ALA, Fonseca RMGS. Projeto copiadora do CAPS Luis Cerqueira: do trabalho de reproduzir coisas à produção de vida. Rev. esc. enferm. USP [Internet]. 2002 Dec; 36(4): 358-66. Doi: http://dx.doi.org/10.1590/S0080-62342002000400010.

12. Silva RS, Moraes M. Musicoterapia e saúde mental: relato de uma experimentação rizomática. PSICO, Porto Alegre, PUCRS, 2007 May-Aug; 38(2): 139-47. revistaseletronicas.pucrs.br/ojs/ index.php/revistapsico/article/.../1988 


\section{INTERNATIONAL ARCHIVES OF MEDICINE

13. Halstead MT, Roscoe ST. Restoring the spirit at the end of life: music as an intervention for oncology nurses. Clin. J. Oncol. Nurs., 2002 Jan; 6(6): 332-6. Doi:10.1188/02.CJON.332-336

14. Araújo TC, Silva LWS. Música: estratégia cuidativa para pacientes internados em unidade de terapia intensiva. Rev. enferm UFPE Online. Recife, 2013 May; 7(5): 1319-25. DOI: 10.5205/ reuol.3960-31424-1-SM.0705201309

15. Cordeiro RC, Freitas LA, Azevedo EB, Costa LFP, Cordeiro RC, Silva G, et al. Musicoterapia como modalidade terapêutica complementar para usuários em situação de sofrimento psíquico. Rev. enferm UFPE online. Recife, 2013 Dec; 7(12):

6725-31. DOI: 10.5205/reuol.2950-23586-1-ED.0712201301

16. Oliveira FB, Fortunato ML. Reabilitação psicossocial na perspectiva da reforma psiquiátrica. Vivência, 2007; 32: 155-61. http://www.cchla.ufrn.br/vivencia/sumarios/32/PDF\%20 para $\% 20$ INTERNET 32/CAP\%2010 FRANCISCA $\% 20$ BEZERRA E MARIA\%20LUCINETE.pdf
Vol. 8 No. 192 doi: $10.3823 / 1791$

\section{Comment on this article:}

\section{(f) in $8+\boldsymbol{S} P$}

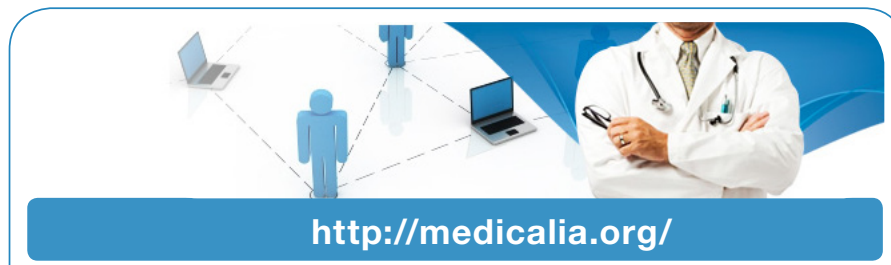

Where Doctors exchange clinical experiences, review their cases and share clinical knowledge. You can also access lots of medical publications for free. Join Now!

\section{Publish with iMedPub}

\section{http://www.imed.pub}

International Archives of Medicine is an open access journal publishing articles encompassing all aspects of medical science and clinical practice. IAM is considered a megajournal with independent sections on all areas of medicine. IAM is a really international journal with authors and board members from all around the world. The journal is widely indexed and classified Q1 in category Medicine. 